\title{
The mechanism of state support for agriculture in the Russian Federation and countries of the world
}

\author{
Ludmila Spektor $^{1,{ }^{*}}$ and Elena Mineeva ${ }^{1}$ \\ ${ }^{1}$ Institute of Service and Entrepreneurship (branch) DSTU in Shakhty, 147 Shevchenko str., Shakhty, \\ Rostov region, 346500, Russia
}

\begin{abstract}
It is necessary to carry out state support in any case, overcoming all difficulties, because not only economic indicators, but also the well-being of the population depend on a successful food policy. In this article, we will be convinced of the need for government assistance for agricultural producers and analyze the most effective methods. Having considered the food policy of the countries of the world, we will identify the features of each of them. Let us also examine the factors that hinder the development of agriculture, endangering human and environmental safety that most countries in the world face.
\end{abstract}

\section{Introduction}

Changes in macroeconomics, different climates and natural conditions on the territory of states, the need to increase the competitiveness of goods on the international market necessitate support and regulation of agro-industrial policy by the state.

Agriculture plays one of the most important roles in the economy of every country in the world since it includes the food industry on which the life of the population directly depends. Therefore, the agricultural industry is actively supported by the governments of most countries in the world. The leading states in terms of agricultural production are currently not using an extensive method of development (an increase in the territory prepared for sowing; an increase in the number of workers in the agricultural sector), but an intensive one (an increase not in the number of territories, but in the quality of soil in these territories; development of technologies used in production, etc.).

Actually, it is precisely to increase the efficiency of production that both farmers and states are striving. What measures does the state use to support agriculture?

\section{Methodology}

The work used the method of analysis and assessment of measures of state support for agriculture in the Russian Federation and other countries of the world to determine the most effective.

\footnotetext{
*Corresponding author: spektor2@yandex.ru
} 


\section{Results of the research}

It is impossible not to mention the World Trade Organization, created in 1995, - an international organization designed to resolve trade disputes and establish rules for trade between member countries, serving as support for developing countries. At the moment, the WTO has 164 participants (Figure 1: green indicates WTO member countries; blue - WTO member countries, also represented through the EU; yellow - observers; red - non-WTO members) [5].

The World Trade Organization in accordance with its norms divides support measures into three "baskets": yellow, blue and green. The "yellow" refers to measures that have a direct impact on agricultural trade. These measures include direct subsidies and grants. The "blue" basket includes measures-restrictions. Farmers, whose production is less in demand, give up their territories and / or livestock and receive compensation for this.The "green" box includes measures that indirectly affect the increase in production. These measures include scientific research, increasing soil fertility, veterinary work, creating state reserves to maintain food security, domestic food assistance, direct payments to producers, and the like.

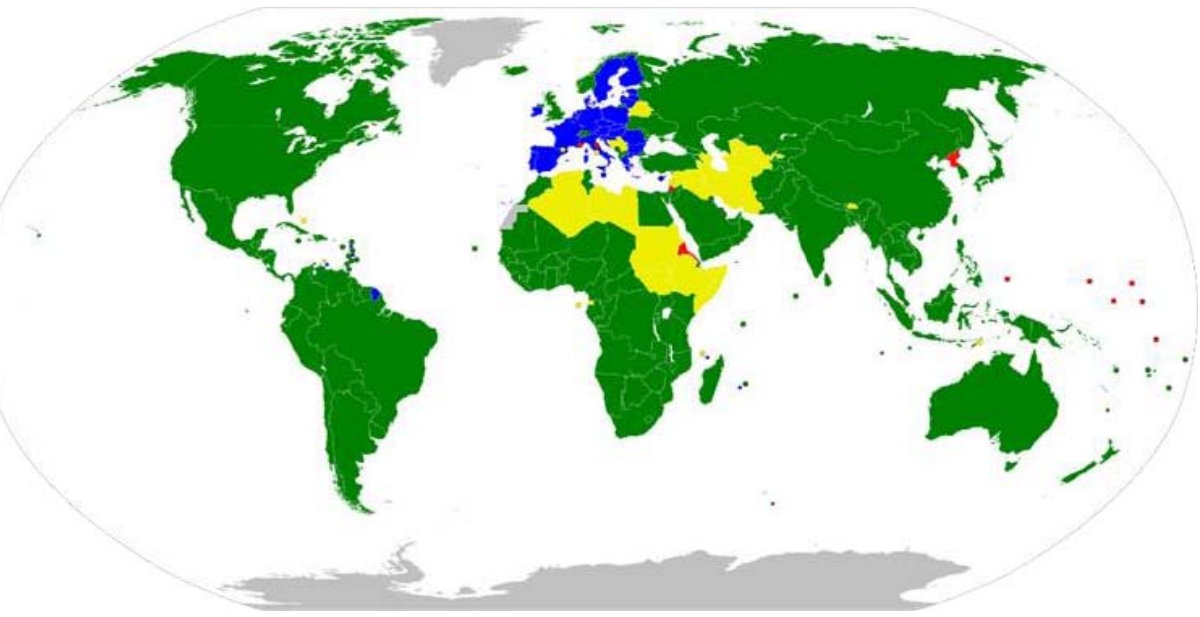

Fig. 1. WTO Membership (Source: https://en.wikipedia.org/wiki/World_Trade_Organization).

Let's consider the mechanism of state support using the examples of specific countries.

\subsection{Russian Federation}

In many developed countries, agriculture enjoys a wide range of government support measures. The main task of states in this regard is to achieve food security and sustainability / profitability of agricultural products on the market.

For the Russian Federation and the state of agricultural production, macroeconomic changes play a significant role. Natural and climatic conditions will either support agriculture and the country's economy as a whole, or they will slow down its development.

The Ministry of Agriculture of the Russian Federation identifies the following measures to support agriculture: various benefits (leasing; lending; tariffs for the transportation of crops, etc.), subsidies (incentive and compensatory; for manufacturers of equipment used in production), compensation and reimbursement of costs.

It is impossible not to mention the emergence of the following state programs: "Comprehensive Development of Rural Areas", the State Program for the Development of Agriculture (including the sustainable development of agricultural lands, scientific research, development of technology used in agro-industrial sectors, providing industry with raw 
materials), as well as the Federal Scientific and Technical agricultural development program for 2017-2025.

At the same time, the reduction and even decline of the gross domestic product, investment of the budget in other branches of production significantly slow down the development of agriculture in Russia. But in a country with about $30 \%$ of black soil, it would be unreasonable to ignore agriculture.

In 2012, the Russian Federation became the 156th member of the World Trade Organization and pledged to comply with all its requirements and principles. Disputes about the favorableness of this event for entrepreneurs are still ongoing, but from the very beginning it was clear that the country's accession to the WTO would bring significant changes in the regulatory environment. Will this be beneficial for Russian companies? It depends on themselves, on their ability to adjust to the situation in time and turn it around so as to pursue their own interests.

One of the leading countries in terms of agricultural production per capita is the United States. The share of agriculture in the US economy is shown in Figure 1.

In 2019, agriculture and food processing accounted for \$ 1.109 trillion of US gross domestic product (5.2 percent). The problem of food security was directly put before the US government. The state sought to fully cover the food needs with its own production and be able to export these products [1]. The state is also actively using measures related to the "green" box. The agricultural policy of the United States usually follows a five-year plan, on the basis of which the so-called "Farmers' Act" is developed [4].

These "laws" govern agricultural programs, farming communities, food production, and so on. The latest of these bills was issued in 2018 (Agricultural Improvement Act of 2018 (2018 Farm Bill)). He approves the policy of insurance of producers of crops, crops and land, credit programs, measures of special support for farmers of certain categories. Little has changed in US agricultural policy in recent years, because these changes would be meaningless. The system of the US agro-industrial market is already quite effective.

\section{Value added to GDP by agriculture and related industries, 2009-19}

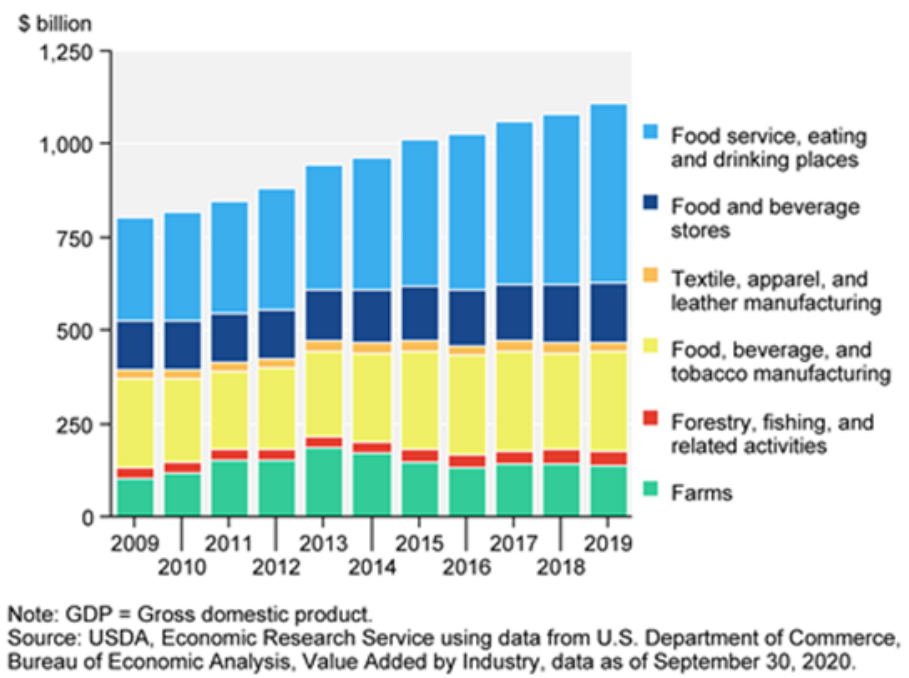

Fig. 2. Share of agriculture in the US economy. (Source: https://www.ers.usda.gov/data-products/agand-food-statistics-charting-the-essentials/). 


\section{$3.2 \mathrm{EU}$}

Regarding the European Union, it is worth noting that agriculture plays a leading role in the countries. Therefore, investing in the development of equipment and farming methods is an integral part of agricultural policy. The demand for food stimulates the EU to invest a significant part of the budget in production, but in addition to this, farmers receive concessional loans, assistance in the sale of products, and direct payments. Measures of all three WTO baskets are being implemented, but the "yellow" basket measures have to be reduced, relying on commitments to the WTO.

Although the EU invests huge amounts of money in the development of agriculture, $70 \%$ of it goes to provide directly to the income of farmers. Small agro-industrial enterprises go bankrupt due to the small size of payments and subsidies, the widespread use of pesticides harms not only the environment, soils [13], but also living organisms, a huge amount of nitrates gets into surface and ground waters due to abundant soil fertilization [14].

By investing in the transition from intensive to extensive farming, environmental restoration, and various means of reducing greenhouse gas emissions, the EU budget would become more effective and help to solve environmental problems [11, 12].

\subsection{Republic of Belarus}

Consider the example of a state like Belarus. As in other countries, the need to maintain food security is emphasized. Differences in natural and climatic conditions that put farmers in an unequal position, macroeconomic changes (thereby increasing the cost of loans and increasing production costs), increased competition in the external and internal markets are inevitable problems that emphasize the need for intervention and support from the state.

The Decree of the President of the Republic of Belarus dated July 17, 2014 specifies the following measures to support agricultural producers: direct action, including direct payments to agricultural production entities from the budget of the republic (as well as local), provision of loans on preferential terms, coverage of costs of entities, financing of state activities; indirect actions include the purchase of raw materials and equipment, preferential taxation, the provision of government guarantees, and the like [2].

\subsection{People's Republic of China}

To maintain food security, China began to pay more attention to agriculture as an important part of the national economy [3]. The state almost $100 \%$ covers food needs through its own production [1,9]. The protection of arable land is part of government policy. The administration of each province of the PRC is directly responsible for food production, for increasing stocks and yields. Taking into account the development of the state and the conditions of the WTO, a system of subsidies for agricultural producers was created, consisting of four subsidies (for the purchase of tools and equipment; direct, for producers of grain crops; comprehensive, to compensate for the costs of means of production; for the purchase of high-quality seeds). Let's take into account that the government of the PRC since 2000 , in connection with the beginning of the agricultural tax reform, has abolished four taxes, which had a great impact on the development of agricultural production. Producers of grain crops and other basic foodstuffs receive government price support in the market. The PRC continues to steadily support and develop agriculture (see Figure 3). 


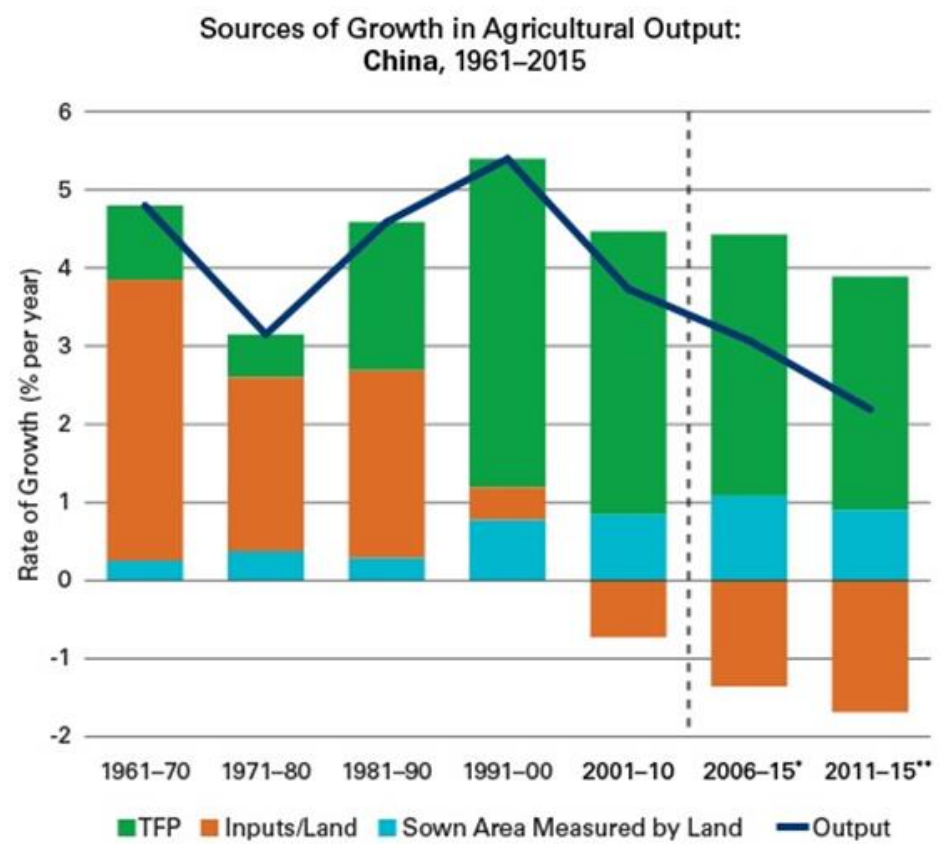

Fig. 3. Sources of agricultural production growth: China, 1961-2015. (Source:

https://globalagriculturalproductivity.org/sustainable-food-and-agriculture-systems-are-built-onproductivity/regional-productivity-growth-progress-and-challenges/china/).

\subsection{Canada}

The Government of Canada is investing \$ 134.4 million to ensure that people have enough safe and nutritious food, and to maintain a clean and green environment. Surveys of the country's population also confirmed the interest of residents in the consumption of natural food[6]. At the present stage, Canada is characterized as a state with a variety of methods to support agriculture, an increased rate of unrelated government support, oriented towards increasing income. The success of food policy is due to the sustainability and competitiveness of Canadian agricultural products in the market.

\section{Discussion of results}

Having analyzed the mechanism of state support for agriculture in different countries of the world, we can identify similar measures. Subsidies, concessional lending, organization and financing of government activities, preferential taxation, transformation of scientific research are common features of most countries that pay attention to agricultural development.

Along with the development of the agricultural mechanism, the problems that the government may face should be considered [7]. Ecological problems:

1. Lack and pollution of water resources;

2. Loss of arable land;

3. Air pollution;

4. Natural and climatic changes [8] and the like.

In addition to environmental ones, we also highlight demographic ones:

1. Decrease in rural population due to migration

2. Reduced labor force 
Economic:

1. Rate increase

2. Food inflation

3. Technical backlog

4. Expensive equipment and fertilizers.

Food safety problems also occur, as the use of pesticides to protect against pests leaves human and environmental protection in question [10].

To achieve sustainable agricultural development, the governments of the countries should unite and solve these global problems by joint efforts, because even such developed countries in the field of agriculture as the United States and China suffer from these problems. [15].

\section{Conclusions}

From all of the above, we can conclude that most countries of the world invest a lot of efforts in the development of agriculture: they make direct payments to farmers, provide subsidies, issue preferential loans, stimulate the development of technologies and equipment used in agricultural production, conduct veterinary work, organize and finance state activities - these measures are undoubtedly effective and efficient.

\section{References}

1. G. Veeck, A. Veeck, H. Yu, Geography and Sustainability 1(2), 109-117 (2020)

2. V.G. Gusakov, Scientific principles of regulation of agricultural development: proposals and implementation mechanisms 1, 79-89 (2020)

3. Xiao-qiang Jiao, Nyamdavaa Mongol, Fu-suo Zhang, Journal of Integrative Agriculture 17(4), 755-764 (2018)

4. G. Rausser, D. Zilberman, Encyclopedia of Agriculture and Food Systems (Academic Press, 2014)

5. L. Cooke, Food Trade and the World Trade Organization, Reference Module in Food Science (Elsevier, 2016)

6. D. Maximiliano Macall, C. Williams, S. Gleim, S.J. Smyth, Journal of Agriculture and Food Research 3 (2021)

7. S.D. Prager, K. Wiebe, Global Food Security 28 (2021)

8. C. Buontempo, R. Hutjes, Ph. Beavis et al., Weather and Climate Extremes 27 (2020)

9. J. Shen, F. Zhang, K.H.M. Siddique, Engineering 4(5) (2018)

10. J. Kaushal, M. Khatri, Sh. Kumar Arya, Ecotoxicology and Environmental Safety 207 (2021)

11. M.W. Scown, M.V. Brady, K.A. Nicholas, One Earth 3(2), 237-250 (2020)

12. G. Pe'er, S. Lakner, Climate, and Biodiversity, One Earth 3(2), 173-175 (2020)

13. V. Silva, H.G.J. Mol, P. Zomer et al., Science of The Total Environment 653, 1532-1545 (2019)

14. W. Fang, Y. Peng, D. Muir, J. Lin, X. Zhang, Environment International 131 (2019)

15. C.G. Mkude, M.A. Wimmer, IFIP Advances in Information and Communication Technology 552, 326-333 (2019) 